\title{
A New DC Micro-grid System Using Renewable Energy and Electric Vehicles for Smart Energy Delivery
}

\author{
Chunhua Liu, K.T. Chau, Chenxi Diao, J. Zhong, Xiaodong Zhang, Shuang Gao, and Diyun Wu \\ Department of Electrical and Electronic Engineering \\ The University of Hong Kong, Hong Kong, China \\ chualiu@eee.hku.hk
}

\begin{abstract}
This paper proposes a new DC micro-grid system, which fully utilizes the renewable energy and electric vehicle for smart energy delivery. The proposed DC grid incorporates the AC supply module, standby energy module, renewable energy module, and storage energy module together, to execute the energy distribution. Hence, this grid system can offer a high quality power for the three types of loads, namely $110 \mathrm{~V}$ AC single-phase output, $48 \mathrm{~V}$ DC output, and $100 \mathrm{~V}$ DC output. The control strategy of the grid system for performing smart energy delivery will be discussed in the full paper. The simulation results will be also given to verify the four operation modes of the grid system.
\end{abstract}

\section{INTRODUCTION}

In present, the concept of smart gird becomes more and more important and familiar to different areas, which covers the traditional power system, renewable energy system, electric vehicles, energy storage technology, communication technology, and so on [1]-[5]. The DC micro-grid system, as a subsystem of the smart grid system, can also incorporate the smart concept into the DC power distribution for smart energy delivery [6], [7]. However, since the smart concept for modern grid is under development, the DC micro-grid system still limits in the traditional configuration. Also, there are very few reports on the new DC micro-grid for practical application. Although the reference [6] presents a new DC micro-grid for high power quality distribution, the renewable energy is not modeled into the grid system. Hence, it is still a conventional model for the DC grid system.

In this paper, a new DC micro-grid system is proposed for the smart energy delivery. The proposed micro-grid system is connected with the $230 \mathrm{~V} \mathrm{AC}$ power source, and integrates the renewable energy sources of wind power and photovoltaic (PV) power, as well as the electric vehicle together. In addition, the proposed DC grid system adopts the battery, ultracapacitor and EV for the energy storage. Hence, the proposed DC micro-grid system can not only provide the high quality power for three types of DC and AC loads, but also achieve many special features and characteristics for smart energy delivery. This paper will give a detail discussion of the system configuration, system control strategy for smart energy delivery, and the corresponding simulation performance.

\section{SYSTEM CONFIGURATION}

Fig.1 shows the configuration of the proposed DC microgrid system. This system consists of the following six subsystems, namely the AC supply module, the standby energy module, the renewable energy module, the storage energy module, the output load module, and the intelligent control module. The AC supply module provides the $230 \mathrm{~V}$ AC power source for the $170 \mathrm{~V}$ DC micro-grid. Actually, by adopting the bidirectional AC/DC converter, the DC microgrid energy can also be fed back to the AC power side. The standby energy module adopts the DC diesel generation system, which can offer the $170 \mathrm{~V}$ DC output directly. Hence, this standby energy module can provide the additional energy for the DC micro-grid in case that the system suffers any unpredictable energy absence. The renewable energy module comprises the wind power and PV power source, which are converted to the $\mathrm{DC} 170 \mathrm{~V}$ by the $\mathrm{DC} / \mathrm{DC}$ and $\mathrm{AC} / \mathrm{DC}$ converter. For the PV power branch, the maximum power point tracking (MPPT) control is used to draw the maximum solar power by tuning the duty cycle of the DC/DC converter. For the wind power branch, a new class of permanent-magnet (PM) brushless machine can be used to capture the wind energy for the micro-grid system [8]-[20]. The storage energy module uses the battery and ultracapacitor as the micro-grid energy storeroom. In addition, the electric vehicle (EV) can also server as the energy storage branch, as well as the power supply branch by the bidirectional DC/DC converter [21][29]. The output load module includes three types of loads, namely the $110 \mathrm{~V}$ single-phase AC load, $48 \mathrm{~V}$ DC load, and the $100 \mathrm{~V}$ DC load, which can cover nearly all common appliances. Moreover, the communication module connects all the inverters, converters, and corresponding power signals by the computers. Therefore, the proposed DC micro grid system can achieve the intelligent and flexible ability to accomplish the smart energy delivery.

The detailed power flow of the proposed DC micro-grid system is shown in Fig. 2. It can be seen that the $170 \mathrm{~V} \mathrm{DC}$ link can obtain the power from seven energy sources, including $230 \mathrm{~V}$ three-phase power, DC diesel generation system, wind power, PV power, battery tank, ultracapacitors 


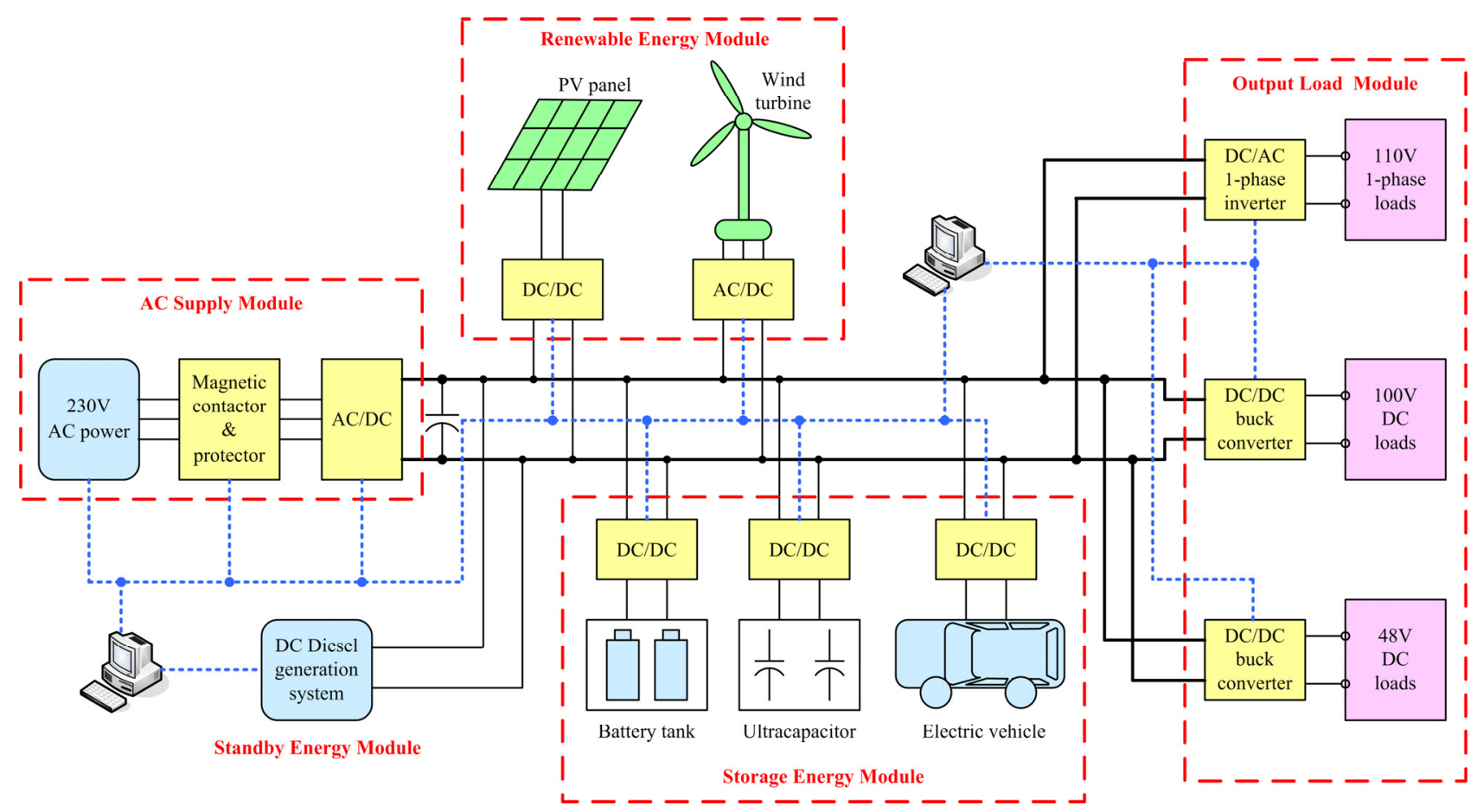

Fig. 1. Proposed DC micro-grid system.

and $\mathrm{EV}$ through $\mathrm{AC} / \mathrm{DC}$ or DC/DC converters. Actually, the renewable energy module is firstly considered to provide the energy to the grid for the energy storage module or the load module. Then, if the demand energy is not enough from the renewable energy module, the $230 \mathrm{~V}$ AC power supply will distribute the energy to the DC micro-grid by the bidirectional AC/DC converter. In addition, if the $230 \mathrm{~V}$ power supply is absent due to any unexpected case, the DC diesel generation system will serve as the standby energy module to offer the energy for the grid. Finally, the 170V DC power will flow to the output load module, which includes three types of loads. Hence, the DC micro-grid can offer the $110 \mathrm{~V}$ AC single-phase output, 100V DC output, and 48V DC output for different load demands.

Fig. 3 shows the information flow of the proposed DC micro-grid system. Firstly, it should be noted that the ten units as shown in Fig. 3 have their own micro-controllers. According to the control strategy, the micro-controller collects the power signals and sends the control signals to the corresponding apparatus (such as converters, protectors, etc.). And all these signal and information are sent to the intelligent control center. Thus, the intelligent control center can execute the setting algorithms for the DC micro-grid system. RS485 is the good choice as the communication protocol between the micro-controller and the intelligent control center. Also, the ZeeBee is a suitable wireless communication candidate for some appliances, such as the EV.

The special features and characteristics of the proposed DC micro-grid system can be summarized as follow:

- The DC micro-grid instinctively possesses the high independent operation ability. Even without the AC power supply, the DC grid can still operate healthily. It means, if an accident occurs in the AC power supply, this grid can aggregate and distribute the power according to the demands.

- By integrating the renewable energy module, storage energy module, standby energy module, and AC supply module together, the proposed micro-grid system can perform smart and flexible energy delivery for the load sides. It means that the grid can distribute the power by optimizing the renewable energy, AC power supply, and storage energy module.

- Since the DC power link inherently has no the harmonic factor, the DC micro-grid can achieve a higher quality power than the traditional AC grid system.

- The DC micro-grid totally removes the transformer, hence improving the power transmission efficiency and downsizing the grid itself.

- $\quad$ The $230 \mathrm{~V}$ AC power supply can be turned off if the grid meets the load demands in such a way that the grid can feed itself and save the energy from outside. Also, if the grid has more energy than the demands, the power can be also fed to the $230 \mathrm{~V}$ AC side by the bidirectional AC/DC converter. In this way, the grid can even sell the power and earn the money.

- The standby energy module usually doesn't provide the power to the grid, which means that the grid achieves the fault-tolerant ability. Furthermore, the diesel generation system directly offers the $170 \mathrm{~V}$ DC power to the grid, hence no requiring any converter.

- The renewable energy module adopts the wind power and PV power branches. Since strong winds are mostly to occur during the nighttime and cloud days whereas 
sunny days are often calm with weak winds, they can compensate each other to some extent during the day and night [30]. Thus, the renewable energy module can continuously offer the power to the grid.

- The battery and ultracapacitor are used as the main energy storage module, which can realize the energy density and power density compensation. In addition, the $\mathrm{EV}$ is also a good auxiliary energy distribution module, since it can attract energy from the grid or feed back energy to the grid.

- The DC grid offers three types of electric power to meet the $110 \mathrm{~V}$ single-phase AC loads, $100 \mathrm{~V}$ DC loads, and $48 \mathrm{~V}$ DC loads. So, it provides the convenient interfaces for different users.

- The standby energy module can offer the auxiliary DC power for the DC grid system in such a way that the DC micro-grid system achieves the fault tolerant ability in accident cases.

- In general, the DC micro-grid is not only a highly independent energy distribution system, but also able to accomplish the energy smart delivery.

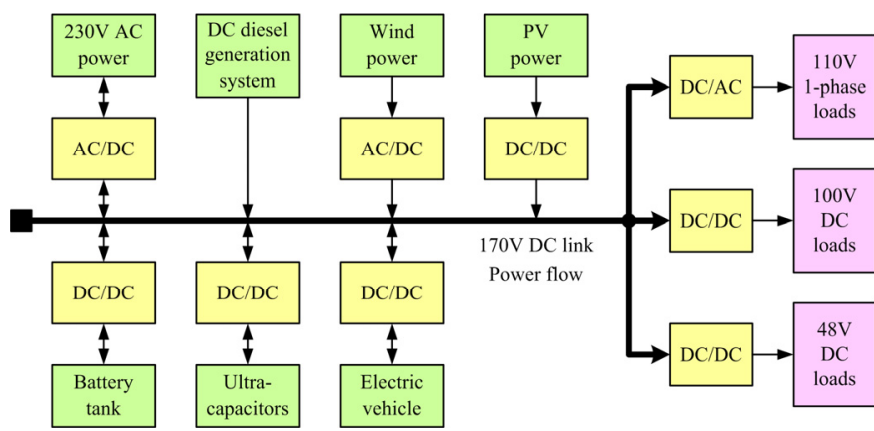

Fig. 2. Power flow of the proposed DC micro-grid system.

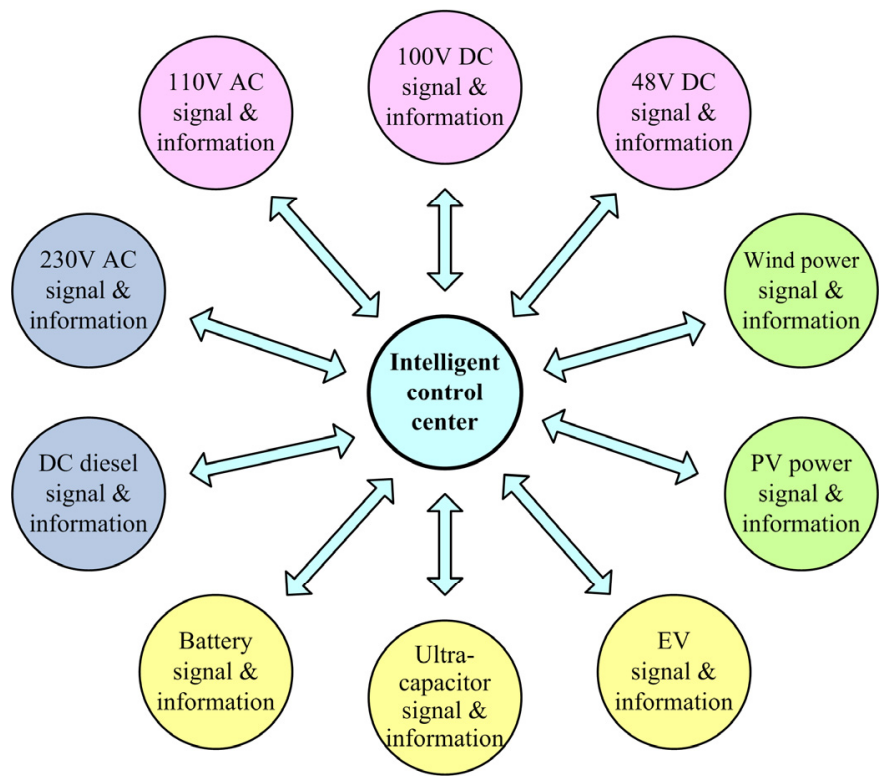

Fig. 3. Information flow of the proposed DC micro-grid system.

\section{CONTROL STRATEGY}

The proposed DC micro-grid system incorporates six modules together, namely the AC supply module, the standby energy module, the renewable energy module, the storage energy module, the output load module, and the intelligent control module. Thus, this gird system possesses the flexible ability to accomplish the smart energy delivery for the loads. To intelligently distribute the power to the load module, four major operation modes are presents for the DC micro-grid system. These four operation modes are summarized as follow.

The first operation mode is the AC energy delivery mode, which only incorporates the AC supply module, the storage energy module, the load module, and the intelligent control module into the DC grid system. Actually, this operation mode is activated when the renewable energy is disabling during the windless days and nights. Hence, according to the practical requirements, the energy can be transferred from the AC supply module to the load module, from the AC supply module to the storage energy module, and from the storage energy module to the load module.

In this $\mathrm{AC}$ energy delivery mode, the intelligent control module assigns the AC supply module to regulate the DC link voltage always at $170 \mathrm{~V}$. And the storage energy module operates at the current-controlled type. Thus, the grid system can maintain the DC link voltage stable for high quality power distribution.

The second operation mode is the renewable energy delivery mode, which only incorporates the renewable energy module, the storage energy module, the load module, and the intelligent control module into the DC grid system. In fact, this operation mode is triggered when the AC supply module is turned off. There are many cases that the DC grid system can fulfill the load requirements without the $\mathrm{AC}$ supply module. It is also worthy to mention that this operation mode shows the value of the renewable energy in the DC microgrid system. Thus, based on the setting strategies, the energy can be distributed from the renewable energy module to the load module, from the renewable energy module to the storage energy module, and from the storage energy module to the load module.

In this renewable energy delivery mode, the intelligent control module allocates the wind generator to work in voltage-controlled type, whereas the PV panel and the storage energy module are operated in current-controlled type. Hence, the grid system always keeps the DC link voltage stable and realizes the smart energy delivery.

The third operation mode is the hybrid energy delivery mode, which integrates all six modules together for smart energy delivery. Actually, the hybrid energy delivery mode is employed when both the traditional AC source and renewable energy source are needed for the loads. So, according to the practical needs, the energy can be transferred from the AC supply module to the load module, from the AC supply module to the storage energy module, from the renewable 
energy module to the load module, from the renewable energy module to the storage energy module, from the storage energy module to the load module, and from the renewable energy module back to the AC supply module.

In this hybrid energy delivery mode for AC supply energy, the intelligent control module appoints the AC supply module to maintain the DC link voltage, whereas it keeps the renewable energy module and storage energy module to operate in current-controlled type. On the other hand, when the $\mathrm{AC}$ module absorbs the energy from the $\mathrm{DC}$ grid, the wind generator will be commanded to work in voltagecontrolled type. And the PV module will be served in currentcontrolled type. Thus, the grid system can maintain the DC link voltage stable with high power quality.

The fourth operation mode is the standby energy delivery mode, which only consists of the standby energy module, the storage energy module, the load module, and the intelligent control module. In fact, this operation mode is activated when the AC supply module and the renewable energy module are shut off at special cases, especially at faulty cases. Hence, based on the practical situation, the energy can be distributed from the standby energy module to the load module and the storage energy module to the load module.

In this standby energy delivery mode, the intelligent control module assigns the standby energy module to work in the voltage-controlled type, as well as the storage energy module to operate in current-controlled type. Thus, the grid system can keep the DC link at stable voltage with high power quality.

In general, the control strategy for the proposed DC grid system is firstly considered to use the renewable energy. Then, it fully utilizes the storage energy to alleviate the grid power stress. In addition, the AC energy is brought into the grid system to fulfill the high power requirements. Furthermore, the standby energy is the auxiliary one, which makes the DC micro-grid system inherently possesses the fault-tolerant ability.

\section{VERIFICATION RESULTS}

The four operation modes are executed and verified by the computer simulation. And the simulation is conducted by the SimPowerSystems of MATLAB/Simulink. The simulated parameters for the grid simulation are summarized as given in Table I. For the battery, it should be noted that due to the long time for the battery charging/discharging, its capacity is rescaled to $1 / 300$. Although the time for battery simulation is rescaled, it still can truly reflect the battery charging/discharging performance in this grid system. Furthermore, since this kind of battery is has a fast charging/discharging ability, it is suitable for EV battery, as well as the EV simulation. In addition, this kind of battery is also suitable for using in EVs, the EV branch is not simulated independently. For the ultracapacitor, 40 units are connected as the tank in series. For the wind power branch, the PM generator is used, which is firstly rectified by the diode bridge and then bucked down by the IGBT bridges to the DC link.
For the PV power branch, an array of $7 \times 4$ PV cells are adopted, which is set to always run in MPPT way by the method of Lookup Table. For the diesel generator, a DC $170 \mathrm{~V}$ type is used, which can directly offer the $170 \mathrm{~V}$ DC output for the DC link. For the three-type of loads, the power rating is set to be $10 \mathrm{~kW}$ each. And the DC output loads use the buck converter to drop down the $170 \mathrm{~V}$ DC to $40 \mathrm{~V}$ and $100 \mathrm{~V}$, whereas the AC output load adopts the full-wave inverter to transfer the $170 \mathrm{~V}$ DC to $110 \mathrm{~V}$ AC. Therefore, based on the aforementioned setting, the four operation modes are calculated as follow.

Firstly, the AC energy delivery mode is performed with the full loads of $30 \mathrm{~kW}$. In this operation mode, the energy distribution is simulated from the AC supply module to the load module, which is given in Fig. 4. It can be seen that the fluctuation of all the DC and AC voltage output is less than $0.5 \%$. In addition, the storage energy module can be also executed for charging and discharging in this grid. Hence, it proves that the proposed DC micro-grid can successfully work in the AC energy delivery mode.

Secondly, the renewable energy delivery mode is calculated with the loads of $15 \mathrm{~kW}$ (5kW at each) firstly and then suddenly increasing the loads of $9 \mathrm{~kW}$ ( $3 \mathrm{~kW}$ at each). In this operation mode, the energy is simulated to deliver from the renewable and storage energy module to the load module, which is shown in Fig. 5. It can be observed that the renewable energy module doesn't change a lot for the current output at load damping time, whereas they keep the output current smooth very fast. Also, from the figure, it can be found that the storage energy module is ordered to release $30 \mathrm{~A}$ current for alleviating the DC link stress. And the storage module can quickly smooth their current output with the acceptable damping. The corresponding DC link and output loads voltage are given in Fig. 6 . Thus, it verifies that the proposed grid can fully use the renewable energy to fulfill the prospected load requirements without the AC supply.

Thirdly, the hybrid energy delivery mode is performed with the rated loads of $30 \mathrm{~kW}$. And the storage module is commanded to attract 50A current from the DC link at some time. In this operation mode, the energy is distributed from the AC supply renewable energy module to the storage and load module. Fig. 7 shows the current waveforms of different modules. It can be found that the fluctuation of each module is very small during the storage module absorbing the energy from the DC link. Furthermore, Fig. 8 shows the DC link and load voltages. It also tells that the maximum fluctuation of the DC link voltage is suppressed fewer than $2.5 \%$ and the load ones are kept down below $0.5 \%$. Hence, they prove that in this operation mode, the DC grid can successfully accomplish the smart energy delivery.

Fourthly, the standby energy delivery mode is executed for the loads of $14 \mathrm{~kW}$ ( $4 \mathrm{~kW}$ each for DC loads) in emergent cases. Fig. 9 shows the corresponding waveforms of the diesel generator, DC link and loads. It illustrates that the grid has a high power quality for the energy distribution. Also, it tells the grid has a high degree of the fault-tolerance. 
TABLE I PARAMETERS SETTING FOR SiMULATION

\begin{tabular}{|c|c|c|c|}
\hline Battery & $\begin{array}{l}\text { Ultra- } \\
\text { capacitor }\end{array}$ & $\begin{array}{l}\text { Wind generator } \\
\text { \& PV panel }\end{array}$ & $\begin{array}{c}\text { Diesel } \\
\text { generator \& } \\
\text { load }\end{array}$ \\
\hline $\begin{array}{c}\text { Manufacturer: } \\
\text { GP }\end{array}$ & $\begin{array}{l}\text { Manufacturer: } \\
\text { NESSCAP }\end{array}$ & $\begin{array}{c}\text { Generator type: } \\
\text { PM machine }\end{array}$ & $\begin{array}{c}\text { Diesel } \\
\text { generator: } \\
\text { DC type }\end{array}$ \\
\hline $\begin{array}{c}\text { Model: } \\
\text { 10/GP100EVH }\end{array}$ & $\begin{array}{c}\text { Model: } \\
\text { ESHSP- } \\
\text { 1700C0-002R7 }\end{array}$ & $\begin{array}{l}\text { Generator rated } \\
\text { power: } 20 \mathrm{~kW}\end{array}$ & $\begin{array}{c}\text { Generator } \\
\text { rated power: } \\
20 \mathrm{~kW}\end{array}$ \\
\hline $\begin{array}{c}\text { Nominal voltage: } \\
240 \mathrm{~V}\end{array}$ & $\begin{array}{l}\text { Rated voltage: } \\
2.7 \times 40 \mathrm{~V}\end{array}$ & $\begin{array}{c}\text { Generator rated } \\
\text { voltage: } 220 \mathrm{~V}\end{array}$ & $\begin{array}{c}\text { Generator } \\
\text { voltage: } 170\end{array}$ \\
\hline $\begin{array}{l}\text { Fully Charged } \\
\text { voltage: } 280 \mathrm{~V}\end{array}$ & $\begin{array}{l}\text { Surge voltage: } \\
2.85 \times 40 \mathrm{~V}\end{array}$ & - & $\begin{array}{c}\text { Generator } \\
\text { current:117.6 }\end{array}$ \\
\hline $\begin{array}{c}\text { Nominal } \\
\text { discharge current } \\
98 \mathrm{~A}\end{array}$ & $\begin{array}{l}\text { Rated current: } \\
\text { 371A }\end{array}$ & $\begin{array}{c}\text { PV } \\
\text { Manufacturer: } \\
\text { Raloss }\end{array}$ & - \\
\hline $\begin{array}{c}\text { Rated capacity: } \\
98 \mathrm{Ah} / 300 \\
\end{array}$ & $\begin{array}{c}\text { Max. current: } \\
>1048 \mathrm{~A}\end{array}$ & $\begin{array}{c}\text { PV connect style } \\
7 \times 4 \\
\end{array}$ & $\begin{array}{c}\text { 110V Load: } \\
10 \mathrm{~kW}\end{array}$ \\
\hline $\begin{array}{l}\text { Max. capacity: } \\
120.4 \mathrm{Ah} / 300\end{array}$ & $\begin{array}{c}\text { Max. energy: } \\
6196.5 \times 40 \mathrm{~J} \\
1.7213 \times 40 \mathrm{Wh}\end{array}$ & $\begin{array}{c}\text { PV panel power: } \\
199.5 \times 28= \\
5.586 \mathrm{~W}\end{array}$ & $\begin{array}{l}\text { 100V Load: } \\
10 \mathrm{~kW}\end{array}$ \\
\hline $\begin{array}{c}\text { Capacity@ } \\
\text { nominal voltage: } \\
51.94 \mathrm{Ah} / 300\end{array}$ & $\begin{array}{c}\text { Rated Cap.: } \\
1700 \mathrm{~F} / 40\end{array}$ & $\begin{array}{c}\text { Rated voltage } \\
\text { under MPPT: } \\
45.7 \times 7=319.8 \mathrm{~V}\end{array}$ & $\begin{array}{l}\text { 48V Load: } \\
10 \mathrm{~kW}\end{array}$ \\
\hline $\begin{array}{c}\text { Exponential zone } \\
248 \mathrm{~V} \\
12.04 \mathrm{Ah} / 300\end{array}$ & $\begin{array}{c}\text { Life: } \\
500000 \text { cycle }\end{array}$ & $\begin{array}{c}\text { Rated current } \\
\text { under MPPT } \\
4.35 \times 4=18.4 \mathrm{~A}\end{array}$ & - \\
\hline
\end{tabular}
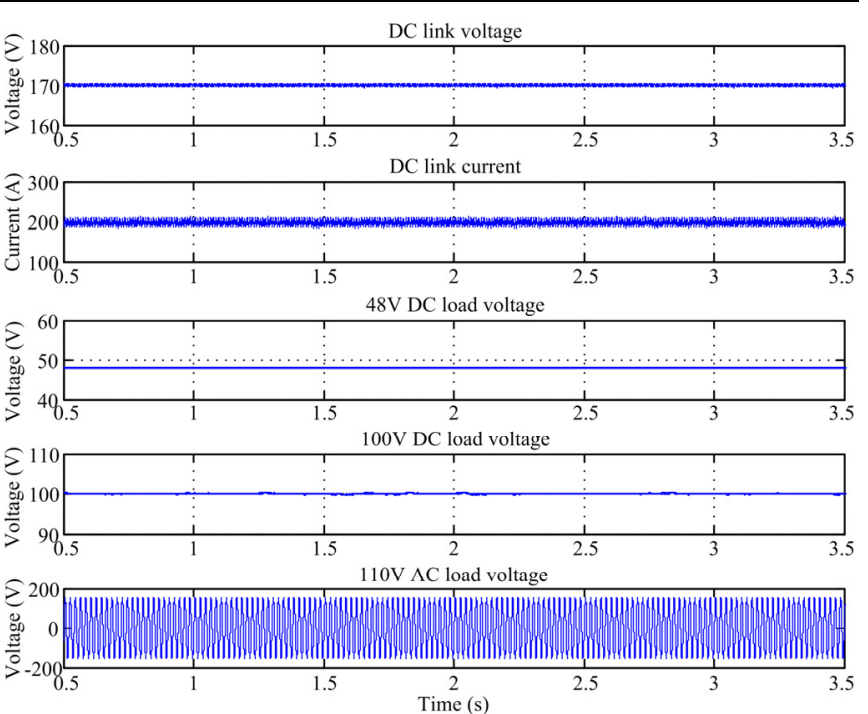

Fig. 4. AC energy delivery mode: output voltage waveforms.
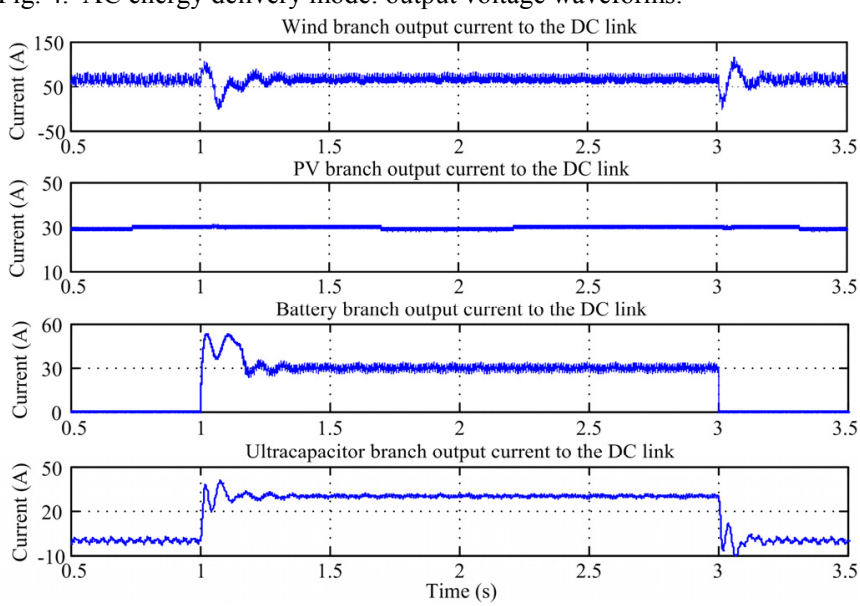

Fig. 5. Renewable energy delivery mode: output current waveforms.
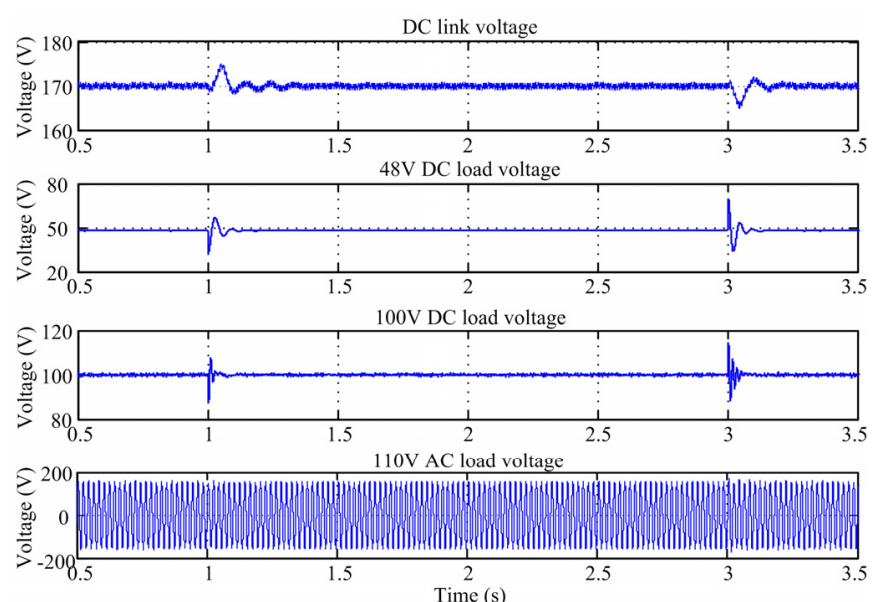

Fig. 6. Renewable energy delivery mode: output voltage waveforms.
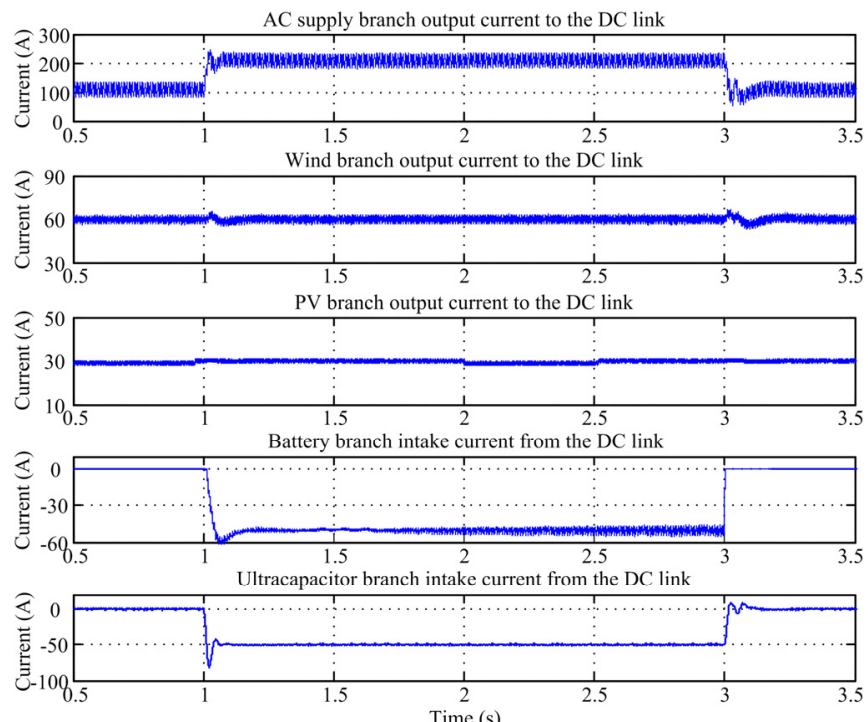

Fig. 7. Hybrid energy delivery mode: output current waveforms.
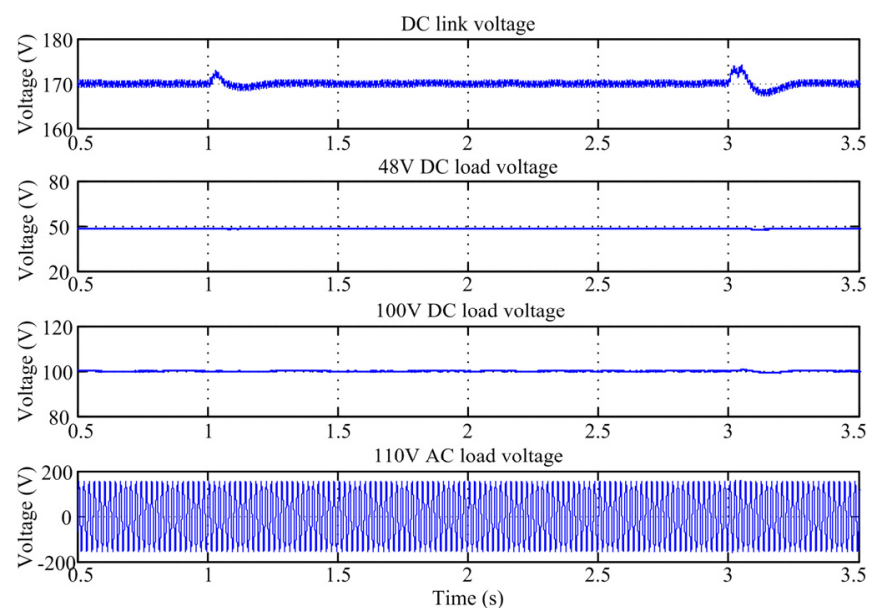

Fig. 8. Hybrid energy delivery mode: output voltage waveforms. 

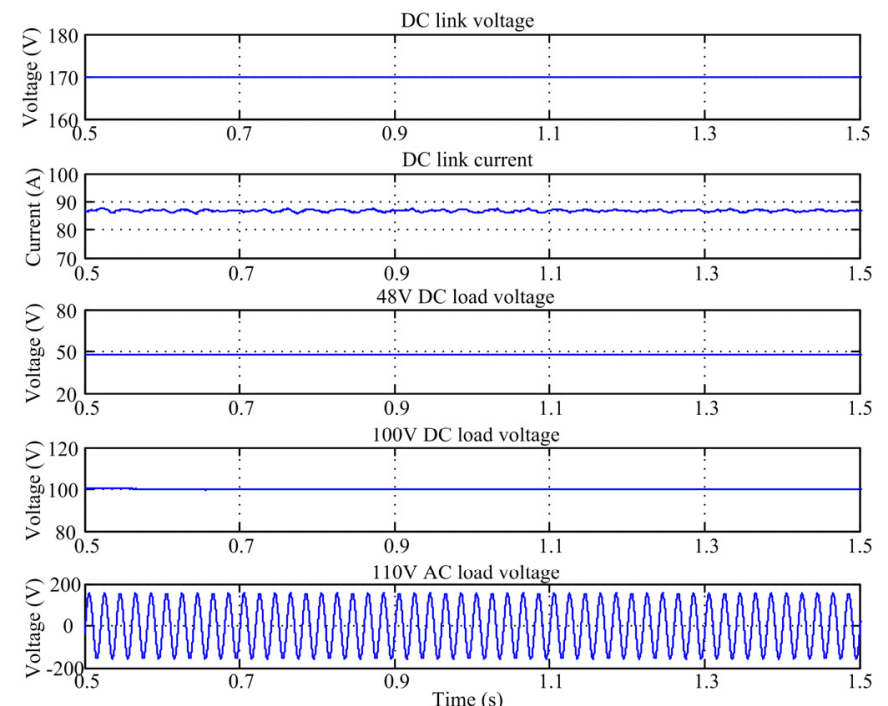

Fig. 9. Standby energy delivery mode: output current $\&$ voltage waveforms.

\section{CONCLUSION}

In this paper, a new DC micro-grid system is presented for smart energy delivery, which integrates the AC supply module, standby energy module, renewable energy module and storage energy module together. So, this grid system can provide a high quality power for $110 \mathrm{~V}$ AC single-phase loads, $48 \mathrm{~V}$ DC loads, and 100V DC loads. Four operation modes of the gird system is discussed and simulated, which proves the validity of the proposed grid system.

\section{ACKNOWLEDGMENT}

This work was supported by HKU Strategic Research Theme and University Development Funding (Initiative on Clean Energy \& Environment, ICEE), the University of Hong Kong, Hong Kong Special Administrative Region, China.

\section{REFERENCES}

[1] H. Farhangi, "The path of the smart grid," IEEE Power and Energy Magazine, Vol. 8. No. 1, pp. 18-28, Jan. 2010.

[2] J. Wang, A. Huang, W. Sung, Y. Liu, and B.J. Baliga, "Smart grid technologies," IEEE Power and Energy Magazine, Vol. 3. No. 2, pp 16-23, June 2009

[3] J. Fan and S. Borlase, "The evolution of distribtuion," IEEE Power and Energy Magazine, Vol. 7. No. 2, pp. 63-68, March/April 2009.

[4] A. Vojdani, "Smart integration," IEEE Power and Energy Magazine, Vol. 6. No. 6, pp. 71-79, Nov./Dec. 2008.

[5] A. Ipakchi and F. Albuyeh, "Grid of the future," IEEE Power and Energy Magazine, Vol. 7. No. 2, pp. 52-62, Jan. 2010.

[6] H. Kakigano, Y. Miura, T. Ise, and R. Uchida, "Dc voltage control of the DC micro-grid for super high quality distribution," Power Conversion Conference, Nagoya, pp. 518-525, 2007.

[7] M. Brenna, C. Bulac, G.C. Lazaroiu, G. Superti-Furga, and E. Tironi, "DC power delivery in distributed generation systems," $13^{\text {th }}$ International Conf. on Harmonicus and quality of Power, pp. 1-6, 2008.

[8] Y. Fan, K.T. Chau and M. Cheng, "A new three-phase doubly salient permanent magnet machine for wind power generation," IEEE Transactions on Industry Applications, Vol. 42, No. 1, , pp. 53-60, January/February 2006.

[9] Y. Fan, K.T. Chau and S. Niu, "Development of a new brushless doubly fed doubly salient machine for wind power generation, IEEE Transactions on Magnetics, Vol. 42, No. 10, pp. 3455-3457, Oct. 2006
[10] K.T. Chau, Y.B. Li, J.Z. Jiang and S. Niu, "Design and control of a PM brushless hybrid generator for wind power application," IEEE Trans. on Magnetics, Vol. 42, No. 10, , pp. 3497-3499, Oct. 2006.

[11] S. Niu, K.T. Chau, J.Z. Jiang and C. Liu, "Design and control of a new double-stator cup-rotor permanent-magnet machine for wind power generation," IEEE Transactions on Magnetics, Vol. 43, No. 6, , pp. 2501-2503, June 2007.

[12] C. Liu, K.T. Chau, J.Z. Jiang and L. Jian, "Design of a new outer-rotor permanent magnet hybrid machine for wind power generation," IEEE Transactions on Magnetics, Vol. 44, No. 6, pp. 1494-1497, June 2008.

[13] C. Liu, K.T. Chau, J.Z. Jiang and S. Niu, "Comparison of statorpermanent-magnet brushless machines," IEEE Transactions on Magnetics, Vol. 44, No. 11, pp. 4405-4408, November 2008.

[14] C. Yu, K.T. Chau and J. Z. Jiang, "A flux-mnemonic permanent magnet brushless machine for wind power generation," AIP Journal of Applied Physics, Vol. 105, No. 7, Paper No. 07F114, pp. 1-3, April 2009.

[15] L. Jian, K.T. Chau and J.Z. Jiang, "A magnetic-geared outer-rotor permanent-magnet brushless machine for wind power generation," IEEE Trans. on Industry Applications, Vol. 45, No. 3, pp. 954-962 May/June 2009.

[16] K.T. Chau, J.Z Jiang and Y. Wang, "A novel stator doubly fed doubly salient permanent magnet brushless machine," IEEE Transactions on Magnetics, vol. 39, no. 5, pp. 3001-3003, September 2003.

[17] Y. Wang, K.T. Chau, C.C. Chan, and J.Z. Jiang, "Transient analysis of a new outer-rotor permanent-magnet brushless dc drive using circuitfield-torque time-stepping finite element method," IEEE Transactions on Magnetics, vol. 38, no. 2, pp. 1297-1300, March 2002.

[18] M. Cheng, K.T. Chau and C.C. Chan, "Static characteristics of a new doubly salient permanent magnet motor," IEEE Transactions on Energy Conversion, vol. 16, no. 1, pp. 20-25, March 2001.

[19] M. Cheng, K.T. Chau, C.C. Chan, and E. Zhou, "Performance analysis of split-winding doubly salient permanent magnet motor for wide speed operation," Electric Machines and Power Systems, vol. 28, no. 3, pp. 277288, March 2000

[20] K.T. Chau, "Computer-aided design of a permanent magnet motor," Electric Machines \& Power Systems, vol. 19, no. 4, pp. 501-511, 1991.

[21] K.T. Chau, Y.S. Wong and C.C. Chan, "An overview of energy sources for electric vehicles," Energy Conversion and Management (ECM), Vol. 40, No. 10, pp. 1021-1039, July 1999.

[22] K.T. Chau and Y.S. Wong, "Hybridization of energy sources in electric vehicles," Energy Conversion and Management, Vol. 42, No. 9, pp. 1059-1069, June 2001.

[23] K.T. Chau and C.C. Chan, "Emerging energy-efficient technologies for hybrid electric vehicles," Proceedings of IEEE (PIEEE), Vol. 95, No. 4, pp. 821-835, April 2007.

[24] K.T. Chau, C.C. Chan and C. Liu, "Overview of permanent-magnet brushless drives for electric and hybrid electric vehicles," IEEE Transactions on Industrial Electronics (TIE), Vol. 55, No. 6, pp. 2246 2257, June 2008.

[25] C.C. Chan and K.T. Chau, "An advanced permanent magnet motor drive system for battery-powered electric vehicles," IEEE Transactions on Vehicular Technology, vol. 45, no. 1, pp. 180-188, February 1996.

[26] K.T. Chau, C.C. Chan, and Y.S. Wong, "Advanced power electronic drives for electric vehicles," Electromotion, vol. 5, no. 2, pp. 42-53, April-June 1998.

[27] M.S.W. Chan and K.T. Chau, "A switched-capacitor boost-multilevel inverter using partial charging," IEEE Transactions on Circuits and Systems II, vol. 54, no. 12, pp. 1145-1149, December 2007.

[28] M.S.W. Chan, K.T. Chau and C.C. Chan, "A new switched-capacitor inverter for electric vehicles," Journal of Asian Electric Vehicles, vol. 4 no. 2, pp. 905-909, December 2006.

[29] Y.S. Wong, K.T. Chau and C.C. Chan, "Battery sizing for plug-in hybrid electric vehicles," Journal of Asian Electric Vehicles, vol. 4, no. 2, pp. 899-904, December 2006.

[30] C. Liu, K.T. Chau, and X. Zhang, "An efficient wind-photovoltaic hybrid generation system using doubly-excited permanent-magnet brushless machine," IEEE Transactions on Industrial Electronics, Vol. 57, No. 3, pp.831 -839, March, 2010. 